\title{
Energy and indoor thermal comfort performance of a Swedish residential building under future climate change conditions
}

\author{
Ambrose Dodoo ${ }^{1, *}$ \\ ${ }^{1}$ Department of Building Technology, Linnaeus University, Växjö, Sweden
}

\begin{abstract}
The latest climate change projections for Sweden suggest mean annual temperature increase of up to $5.5^{\circ} \mathrm{C}$ by 2100 , compared to $1961-1990$ levels. In this study we investigate the potential impacts of climate change on the energy demand for space conditioning, overheating risk and indoor thermal comfort of a modern multi-storey residential building in Sweden. We explore climate change adaptation strategies to improve the building's performance under the climate change conditions, including increased ventilation, solar shading, improved windows and mechanical cooling. The building is analysed under future climate projections for the 2050-2059 time frame, with representative concentration pathway (RCP) 2.6, 4.5 and 8.5 scenarios. The building's performances under these future climates are compared to those under the historical climate of 1961-1990 and recent climate of 1981-2010. The results suggest that climate change will significantly influence energy performance and indoor comfort conditions of buildings in the Swedish context. Overheating hours and Predicted Percentage of Dissatisfied (PPD) increased significantly under the future climate scenarios. Furthermore space heating demand is reduced and cooling demand is increased for the studied building. However, effective adaptation strategies significantly improved the buildings' energy and indoor climate performances under both current and future climate conditions.
\end{abstract}

\section{Introduction}

The latest assessment report of the Intergovernmental Panel on Climate Change reiterated that increasing levels of anthropogenic greenhouse gases (GHGs) in the atmosphere is destabilizing the earth's climate system [1]. Anthropogenic activities are estimated to have caused between $0.8^{\circ} \mathrm{C}$ to $1.2^{\circ} \mathrm{C}$ warming of the earth's climate since the pre-industrial period [2]. Furthermore, global land surface average temperatures for the period 2015-2019 are reported to be the highest on modern record, with 2019 being the second warmest year, after $2016[3,4]$. Climate observations in Sweden show that a warming of about $1.0^{\circ} \mathrm{C}$ has already occurred since 1960 [5]. With the current rate of increase, the global warming is projected to reach $1.5^{\circ} \mathrm{C}$ between 2030 and 2052, unless timely and appropriate actions are taken to reduce GHGs emissions [2].

Fossil fuels account for a vast share of the primary energy use in our society today [6, 7], and contribute considerably to climate change $[1,8]$. The International Energy Agency anticipates that global $\mathrm{CO}_{2}$ emission may increase by $20 \%$ by 2035 with the current trends in energy use and planned measures to mitigate climate change [9]. This might result in global average temperature rise of about $3.6^{\circ} \mathrm{C}$ relative to pre-industrial levels, much more than suggested in the Paris climate agreement [10, 11]. The Paris climate agreement suggests keeping temperature rise below $2^{\circ} \mathrm{C}$ and aiming for a temperature rise of $1.5^{\circ} \mathrm{C}[11]$.
Buildings are responsible for about $36 \%$ of $\mathrm{CO}_{2}$ emissions in the European Union (EU) [12], contributing substantially to climate change. In consequence, climate change will impact on buildings' energy and indoor climate performance $[13,14]$. Mitigation and adaptation strategies may be implemented to minimise potential risks that may be associated with climate change. Climate change mitigation strategies seek to minimise emissions of atmospheric GHGs, while climate change adaptation strategies may aim to ensure tolerable and resilient performance of the built environment. Adaptation measures for buildings may aim at ensuring comfortable indoor climate and could encompass passive and active measures to reduce cooling load and overheating risk which are expected to be dominant under climate change conditions $[15,16]$.

Studies to increase understanding of how climate change may affect thermal performance of buildings are essential to inform appropriate climate mitigation and adaptation strategies. Generally, studies in different countries reported significant changes in building space conditioning energy use, with the dominance of cooling increasing and heating decreasing, under future climate change scenarios [16-22]. However, the overall effect of the projected future climate change varies significantly for different locations and buildings.

Few studies in Sweden have been reported on the implications of climate change for energy and indoor climate performance of buildings, with most of these based on the Special Report on Emissions Scenarios

Corresponding author: ambrose.dodoo@lnu.se 
(SRES) or simplified future weather data, e.g. $[15,19$, 23, 24]. Fewer Swedish studies, e.g. [25, 26] are based on the representative concentration pathway (RCP) climate scenarios which are the latest set of future climate projections [1]. Still, these studies mostly focused on the potential impacts on space heating and cooling. Swedish studies which also analyse the impact of climate change on indoor thermal comfort are lacking. Thorsson et al. [27] investigated the implications of climate change for outdoor thermal comfort conditions in the Swedish city of Gothenburg, focusing on the influence of urban geometry.

In this study we investigate the potential changes in space conditioning energy demand and thermal comfort of a Swedish case-study building due to future climate change. We explore climate change adaptation strategies to improve the building's thermal performance under the climate change conditions.

\section{Methods}

Energy balance and indoor climate modelling are used in this study to explore the implications of future changes in climate for a case-study apartment building.

\subsection{Case-study building}

The building for this analysis is a six-storey reinforced concrete structure with 24 apartments, built in 2014 in

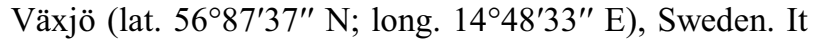
is heated with district heat and has mechanical ventilation with heat recovery (VHR) system. No mechanical cooling system is installed in the building, as with typical Swedish residential buildings, due to the low cooling loads presently. Fig. 1 presents the building's photograph and layout, and Table 1 gives its key thermal characteristics.
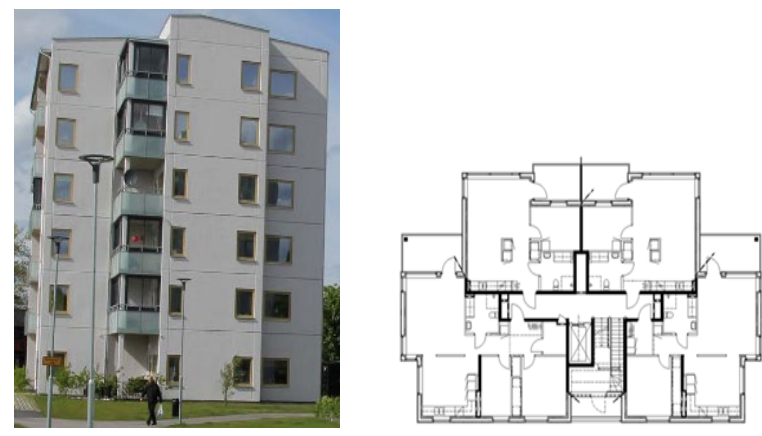

Fig. 1. Photograph and ground floor plan of the building.

Table 1. Construction and thermal properties of the building.

\begin{tabular}{ll}
\hline Description & Values \\
\hline Living / common area $\left(\mathrm{m}^{2}\right)$ & $1420 / 266$ \\
Elements U-values $\left(\mathrm{W} / \mathrm{m}^{2} \mathrm{~K}\right):$ & \\
Ground floor & 0.11 \\
Exterior walls & 0.32 \\
Windows & 1.2 \\
Doors & 1.2 \\
Roof & 0.08 \\
Infiltration $\left(1 / \mathrm{s} \mathrm{m}^{2} @ 50 \mathrm{~Pa}\right)$ & 0.6 \\
\hline
\end{tabular}

\subsection{Climate datasets and future scenarios}

\subsubsection{Historical and recent climates}

As baselines, the thermal performance of the building is modelled with the long-term historical climate dataset for 1961-1990, which denotes the climate normal period in Sweden [28], and with the climate dataset for the period 1981-2010 which is considered to represent the recent climate.

\subsubsection{Future climate scenarios}

RCP2.6, RCP4.5 and RCP8.5 climate change scenarios for the 2050-2059 (2050s) time frame are considered in this study. These scenarios respectively represent low, medium and high climate change projections for the time frame considered. Regionally downscaled HadGEM2-ES data for these scenarios from the RCA4 model [29] are used in this analysis. Fig. 2 shows projected temperature changes for the scenarios for Växjö's county of Kronoberg. The temperature changes are relative to the average for 1960-1990.
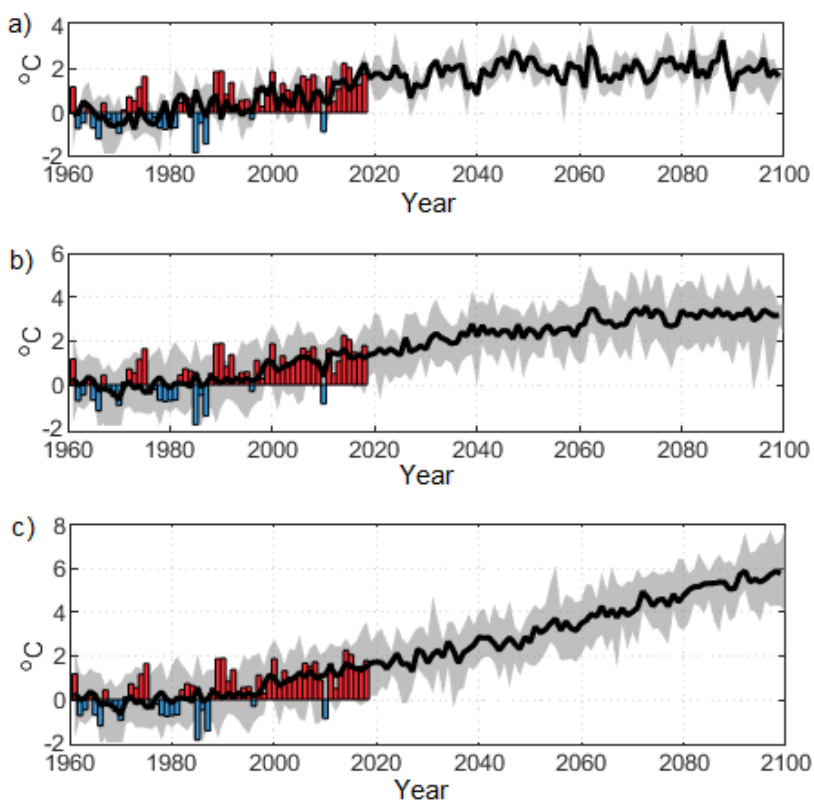

Fig. 2. Temperature changes relative to 1960-1990 average for Växjö's county of Kronoberg, for RCP 2.6 (a), RCP 4.5 (b) and RCP 8.5(c), (Adapted from [5]).

Table 2 presents a summary of the average, maximum and minimum outdoor air temperatures for the climate datasets and scenarios.

Table 2. Outdoor air temperatures for climate datasets and scenarios.

\begin{tabular}{llll}
\hline \multirow{2}{*}{ Description } & \multicolumn{3}{c}{ Outdoor air temperature $\left({ }^{\circ} \mathbf{C}\right)$} \\
\cline { 2 - 4 } & Average & Maximum & Minimum \\
\hline Historical (1961-1990) & 6.4 & 27.5 & -16.0 \\
Recent (1996-2005) & 7.0 & 28.0 & -17.0 \\
RCP2.6-2050s & 8.0 & 29.0 & -14.0 \\
RCP4.5-2050s & 9.0 & 29.0 & -14.0 \\
RCP8.5-2050s & 10.0 & 29.0 & -13.0 \\
\hline
\end{tabular}


Fig. 3 shows projected wind gust under the future scenarios for the studied location.
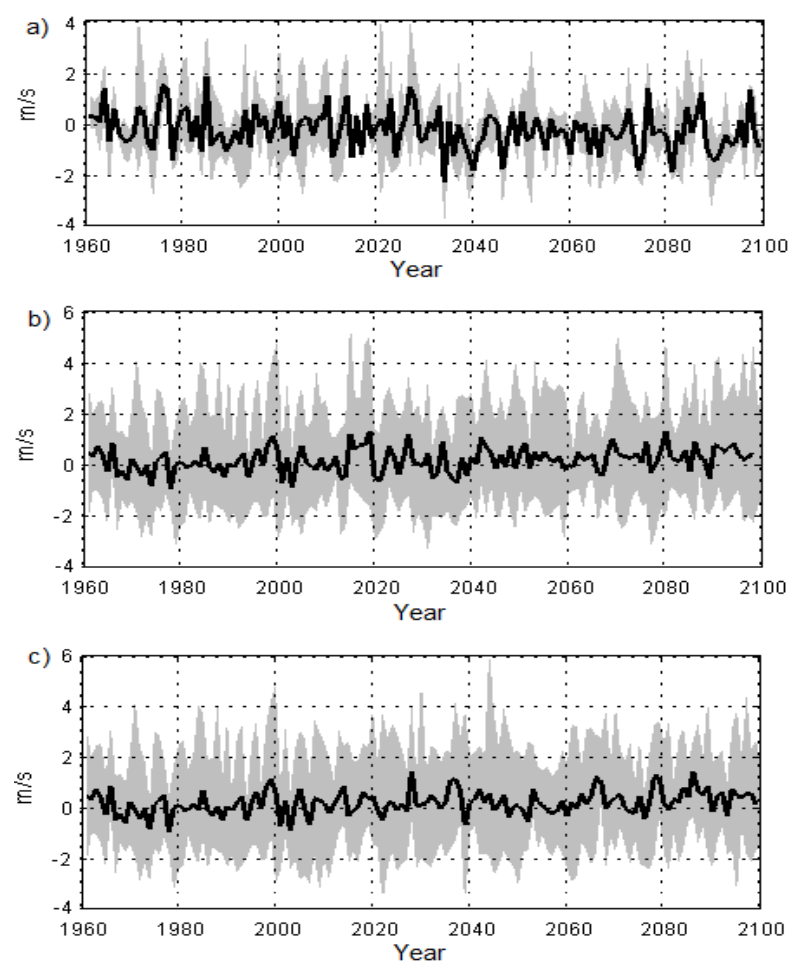

Fig. 3. Wind gust changes relative to $1960-1990$ average for Växjö's county of Kronoberg, for RCP 2.6 (a), RCP 4.5 (b) and RCP 8.5(c), (Adapted from [5]).

\subsection{Climate datasets downscaling}

The future climate scenarios datasets from the RCA4, encompassing outdoor air temperature, solar radiation, wind speed and relative humidity, are at monthly timestep and are downscaled to hourly time-step using an approach described by Belcher et al. [30]. The approach consist of shifting and stretching a baseline hourly climate data with adjustment algorithms that takes into account future monthly mean climate values projected for climate change conditions. The 1961-1990 climate dataset is used as baseline in the downscaling.

\subsection{Simulations and analyses}

\subsubsection{Energy balance modelling}

The VIP-Energy software [31] is used to model the energy and indoor thermal performances of the building under the historical, recent and projected future climates for Växjö. The software is a dynamic simulation program which models energy balance and indoor climate of buildings in hourly time-step. It is a whole building energy simulation program and it calculates the energy demand for heating, cooling, lighting and ventilating a building. Major input parameters taken into account when conducting simulations in VIP-Energy include thermal envelope properties, orientations, HVAC systems, heat gains from lighting, appliances and human bodies, and occupancy and building operation schedules, indoor air temperature and outdoor climate parameters including dry bulb temperature, wind velocity, relative humidity and direct normal radiation. Validations with International Energy Agency's BESTEST, ASHRAE 140-2007 and CEN 15265 showed that the software can give accurate predictions of buildings' thermal performances in comparison with other state-of-the art simulation programs. Key input data for the energy balance analysis are presented in Table 3.

Table 3. Key data for the energy balance modelling.

\begin{tabular}{lll}
\hline Parameter & Data & Remark/Source \\
\hline Heating set-point & $22 / 18^{\circ} \mathrm{C}$ & Living / common areas, [32] \\
Cooling set-point & $26^{\circ} \mathrm{C}$ & Dodoo et al. [32] \\
Heat gains: & & \\
Persons & $1.00 \mathrm{~W} / \mathrm{m}^{2}$ & Dodoo et al. [32] \\
Electrical process & $2.74 \mathrm{~W} / \mathrm{m}^{2}$ & Standard appliances, [33] \\
Sun & Calculated & VIP-Energy simulation [31] \\
Ventilation: & & \\
Air change rate & $0.351 / \mathrm{s} \mathrm{m}^{2}$ & Building code [34] \\
Fan efficiency & $50 \%$ & Camfil [35] \\
VHR efficiency & $75 \%$ & Dodoo et al. [32] \\
Building occupancy & $15 \mathrm{hrs} /$ day & 5.00 pm-8.00 am, [33] \\
\hline
\end{tabular}

\subsubsection{Thermal comfort modelling}

Hourly indoor air and operative temperatures as well as Predicted Percentage Dissatisfied (PPD) index during summer are modelled for the living area of the building for the different climates, using the VIP-Energy software [31]. The PPD index is calculated according to ISO7730 [36], based on the climate file data and VIP-Energy's default assumption on person's clothing and metabolism.

The risk of overheating is analysed for the living area of the building under the different climates considering different guidelines - (i) the Swedish National Board of Health and Welfare recommendation which suggests that indoor air temperatures in residential buildings should not exceed $26^{\circ} \mathrm{C}$ during summer [37], and (ii) the Chartered Institution of Building Services Engineers guideline which suggests that a building is overheated if indoor temperature exceeds $28{ }^{\circ} \mathrm{C}$ in living areas or 26 ${ }^{\circ} \mathrm{C}$ in bedrooms for more than $1 \%$ of the occupied time within a year [38].

\subsubsection{Adaptation strategies}

Plausible measures are analysed to explore strategies to reduce cooling demands and overheating risks, and thereby improve the building's indoor thermal performance under climate change conditions. The analysed measures include increased ventilation rate and implementation of external window shading devices, besides mechanical cooling with air conditioners. The external shading devices are assumed to be fitted above the windows and activated if indoor air temperature exceeds $26^{\circ} \mathrm{C}$. The minimum ventilation rate of $0.35 \mathrm{l} / \mathrm{s}$ $\mathrm{m}^{2}$ required by the Swedish building code is assumed to be doubled when the indoor temperature exceeds $26^{\circ} \mathrm{C}$. The building is modelled with and without the measures 
to evaluate their effectiveness under the different climates and scenarios.

\section{Results}

\subsection{Energy performance}

Fig. 4 shows the annual energy balance of the building under the different climates and demonstrates the contributions of different energy flows for the building. Heat supply, encompassing space and tap water heating, dominates for the supplied energy whiles transmissions dominates the emitted energy. Transmissions and ventilation heat losses, and hence heat supply decreased under the future climate scenarios. Space cooling accounts for a small share of the energy flow, and becomes increasingly noticeable under the future climates.

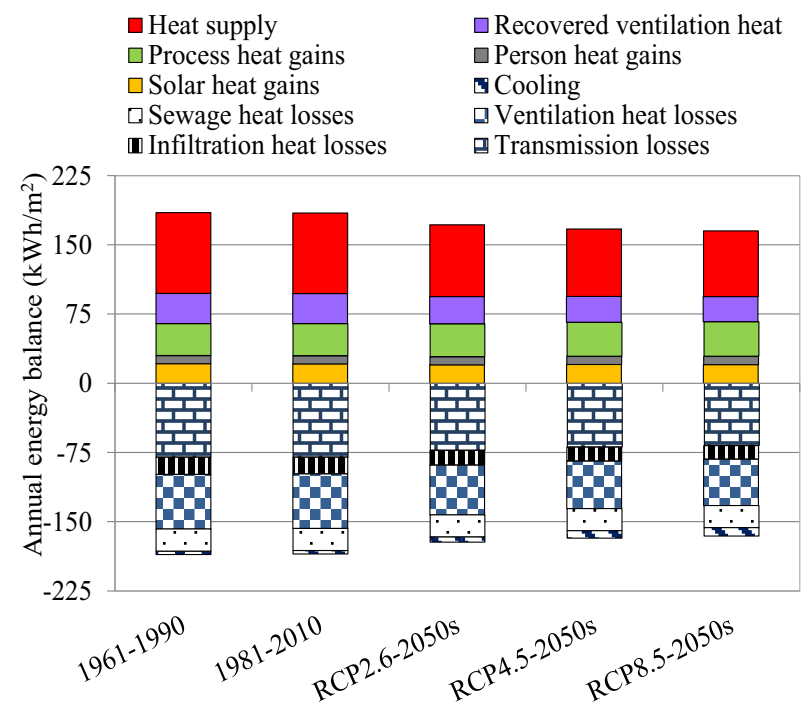

Fig. 4. Annual energy balance of the building under the different climates.

Fig. 5 shows the annual space heating and cooling demands of the building under the different climates. The energy demands for space heating decreased whilst space cooling increased under the future climates.

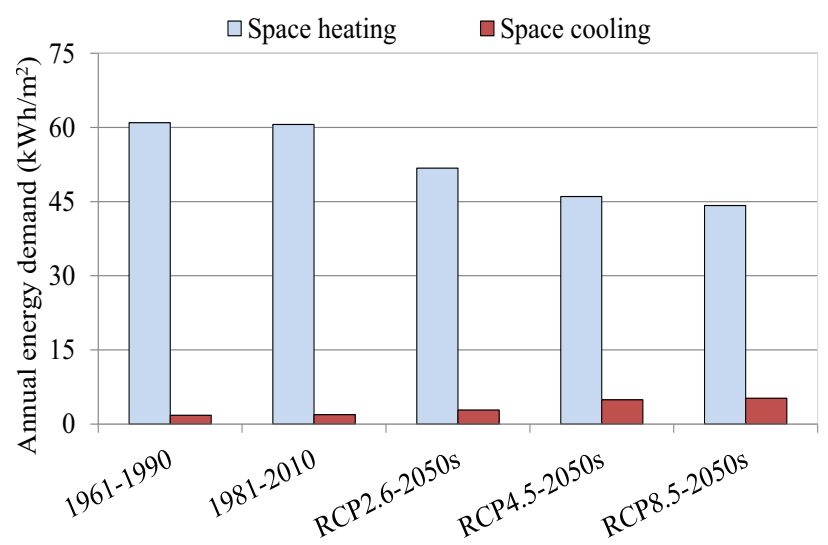

Fig. 5. Annual energy demands for space heating and cooling of the building under historical, recent and future climates.
As shown in Fig. 6, the space heating demand of the building decreased $1 \%, 15 \%, 25 \%$ and $27 \%$ under the recent (1981-2010), RCP2.6-2050s, RCP4.5-2050s and RCP8.5-2050s climates, respectively, relative to the historical (1961-1990) climate. Correspondingly, space cooling demand of the building increased by $5 \%, 60 \%$, $175 \%$ and $192 \%$, respectively.

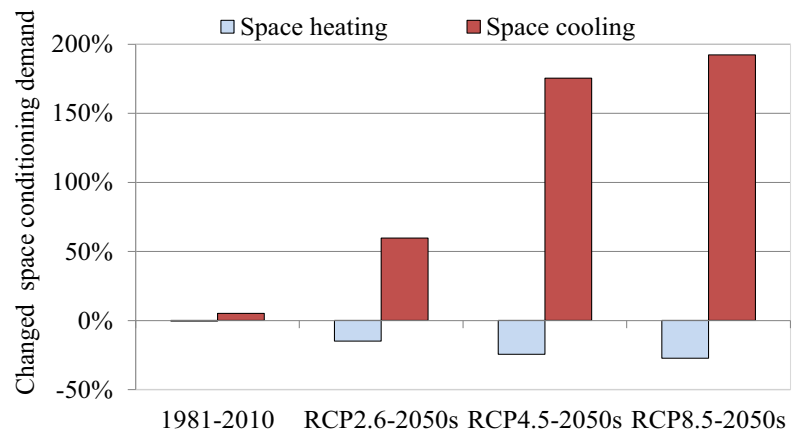

Fig. 6. Changed annual space heating and space cooling demands relative to the historical climate of 1961-1990.

\subsection{Comfort performance}

Fig. 7 gives the hourly indoor air temperature profiles of the living area of the building without cooling intervention under the historical (1961-1990) and recent (1981-2010) climates, while Fig. 8 gives that under the future climates of RCP2.6-2050s, RCP4.5-2050s and RCP8.5-2050s. These show that indoor air temperatures increased between June and August under the future climates compared to the historical and recent climates. Fig. 9 gives the outdoor air temperature as well as the operative temperature of the building without cooling intervention for the RCP4.5-2050s scenario.

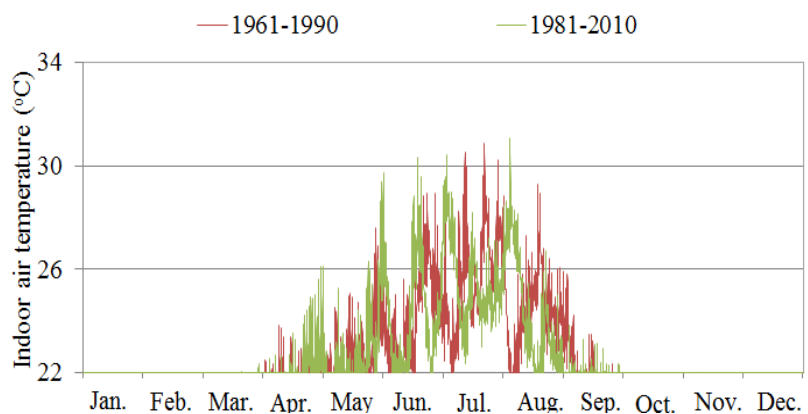

Fig. 7. Annual hourly indoor air temperatures for the building without cooling intervention for historical and recent climates.

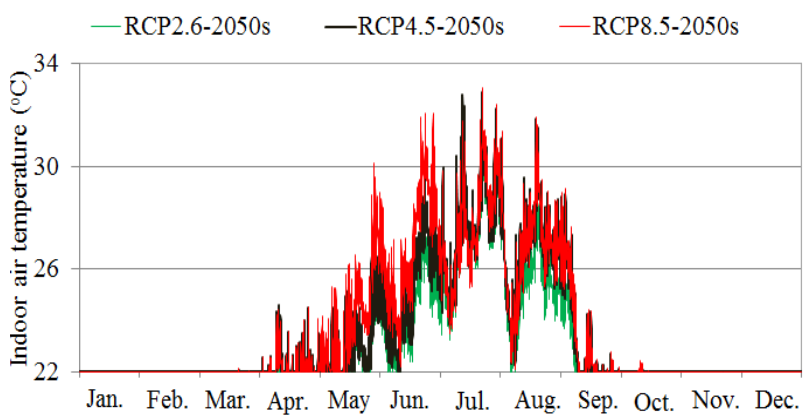

Fig. 8. Annual hourly indoor air temperatures for the building without cooling intervention under future climate scenarios. 


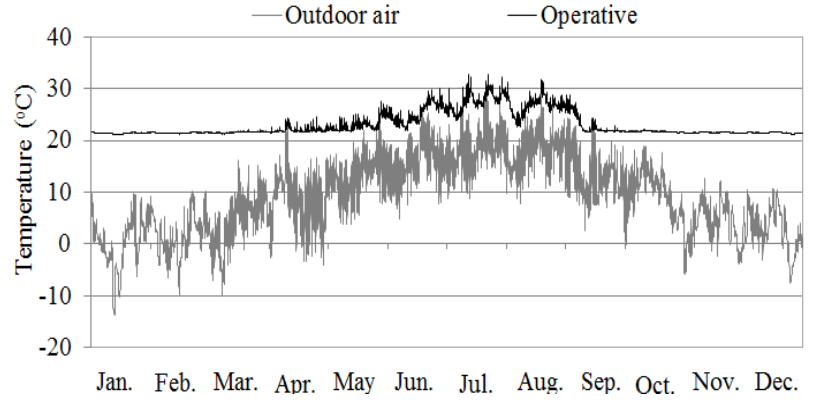

Fig. 9. Annual hourly outdoor air temperature and operative temperature for the building without cooling intervention for RCP4.5-2050s scenario.

Average hourly indoor air and operative temperatures as well as PPD values for the living area of the building during summer ( $1^{\text {st }}$ June to $31^{\text {st }}$ August) under the different climates are summarized in Table 4 . The average indoor air temperatures are about 1.0, 1.8 and $2.4^{\circ} \mathrm{C}$ higher for the RCP2.6-2050s, RCP4.5-2050s and RCP8.5-2050s climates, respectively, compared to the recent climate of 1981-2010. The trend is similar for the operative temperatures. The PPD values for summer increased significantly under the future climates, suggesting that discomfort of occupants will rise under climate change conditions.

Table 4. Average hourly indoor air and operative temperatures and PPD values in summer ( $1^{\text {st }}$ June to $31^{\text {st }}$ August $)$ for the building under different climates.

\begin{tabular}{llll}
\hline Description & $\begin{array}{l}\text { Indoor air } \\
\text { temperature }\end{array}$ & $\begin{array}{l}\text { Operative } \\
\text { temperature }\end{array}$ & $\begin{array}{l}\text { PPD- } \\
\text { index }\end{array}$ \\
\hline $1961-1990$ & 24.7 & 24.8 & 56.6 \\
$1981-2010$ & 24.7 & 24.7 & 63.9 \\
RCP2.6-2050s & 25.7 & 25.7 & 85.0 \\
RCP4.5-2050s & 26.5 & 26.5 & 88.1 \\
RCP8.5-2050s & 27.1 & 27.1 & 90.4 \\
\hline
\end{tabular}

The distributions of the summer hourly indoor air temperatures under the different climates are shown in Fig.10 with boxplot. The maximum temperatures range from 30.9 to $33.0^{\circ} \mathrm{C}$ whilst the minimum temperature remains $22^{\circ} \mathrm{C}$ under the different climates.

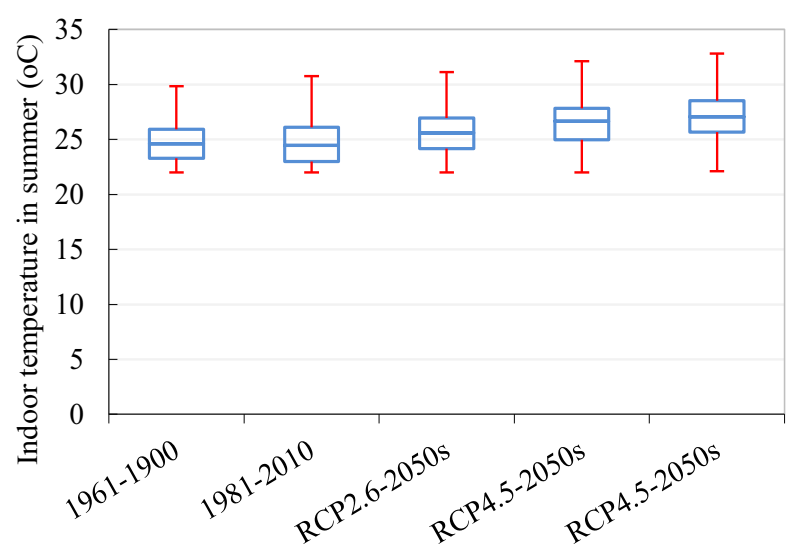

Fig. 10. Distributions of the summer hourly indoor air temperatures under the different climates.

\subsection{Adaptation strategies}

Fig. 11 shows the number of hours for which the indoor air temperatures of the living area of the building exceeded various overheating thresholds for the longterm historical climate of 1961-1990, for cases with and without overheating control intervention.

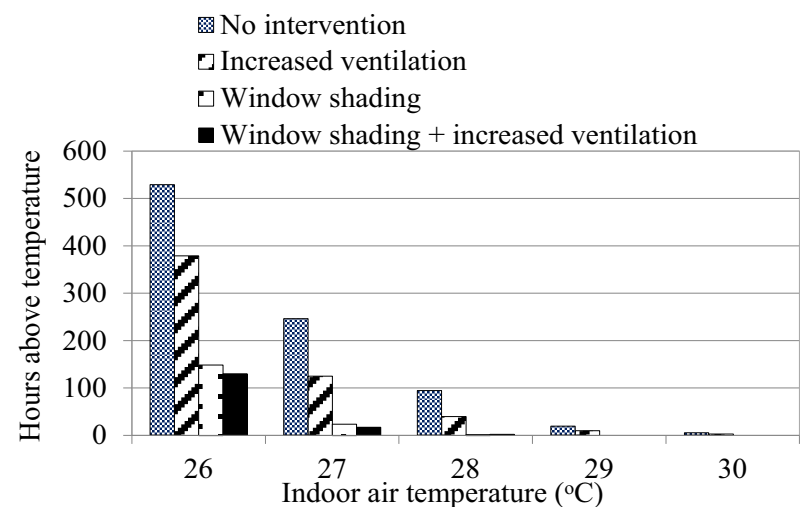

Fig. 11. Hours for which the indoor air temperatures exceeded various overheating thresholds for historical climate (19611990).

Fig. 12 and 13 show the number of hours for which the indoor air temperatures exceeded different thresholds for the recent and RCP4.5-2050s climates, respectively. Overheating hours significantly increased under the RCP4.5-2050s compared to the recent climate.

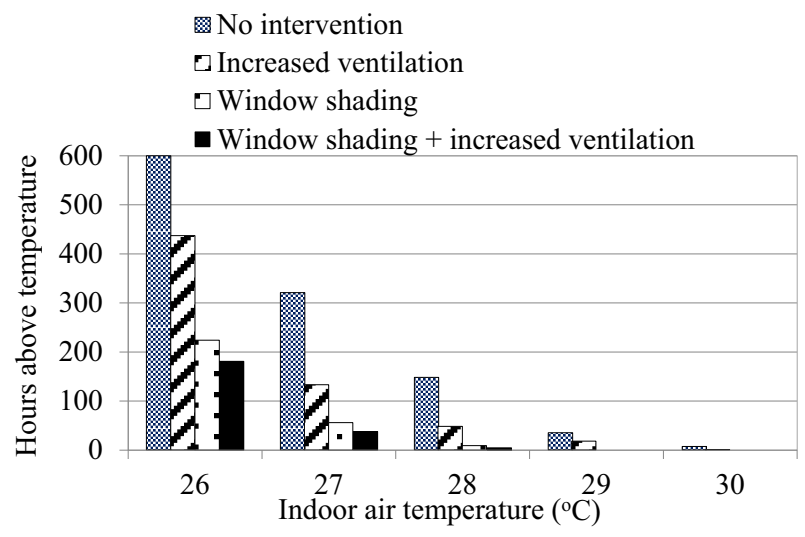

Fig. 12. Hours for which the indoor air temperatures exceeded various overheating thresholds for recent climate (1981-2010).

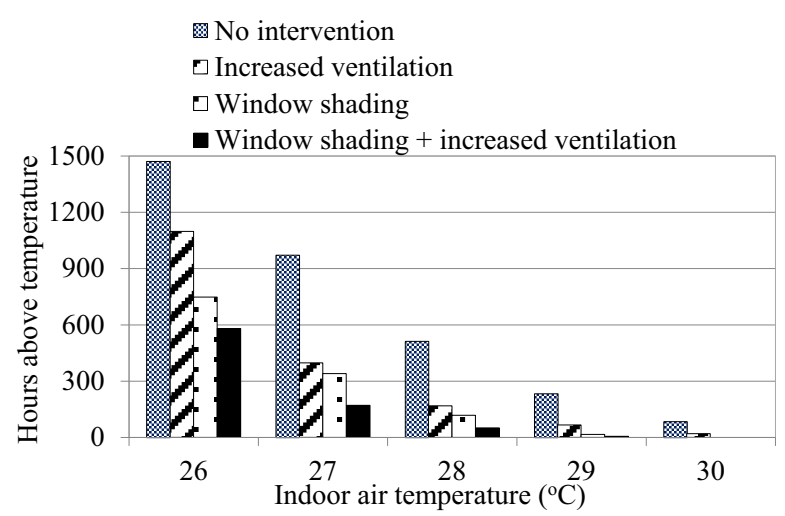

Fig. 13. Hours for which the indoor air temperatures exceeded various overheating thresholds for the RCP4.5-2050s scenario. 
In Table 5, the percentages of the occupied hours with the indoor air temperatures above the various thresholds are summarized for the building under the different climates. The hours with indoor temperatures exceeding the various thresholds increased considerably for the future climates, in contrast to the recent climate. Overall, the overheating control strategies, mainly window shading, significantly reduced the number of hours of discomfort temperatures.

Table 5. Percentage (\%) of the occupied hours with the indoor air temperatures above various discomfort thresholds.

\begin{tabular}{lccccc}
\hline Description & \multicolumn{5}{c}{ \% of hours above temperatures } \\
\cline { 2 - 6 } & $26^{\circ} \mathrm{C}$ & $27^{\circ} \mathrm{C}$ & $28^{\circ} \mathrm{C}$ & $29^{\circ} \mathrm{C}$ & $30^{\circ} \mathrm{C}$ \\
\hline 1961-1990: & & & & & \\
No intervention & 9.7 & 4.5 & 1.7 & 0.3 & 0.1 \\
Increased ventilation & 6.9 & 2.3 & 0.7 & 0.2 & 0.1 \\
Window shading & 2.7 & 0.4 & 0.0 & 0.0 & 0.0 \\
Window shading + & & & & & \\
increased ventilation & 2.4 & 0.3 & 0.0 & 0.0 & 0.0 \\
\hline 1981-2010: & & & & & \\
No intervention & 11.0 & 5.9 & 2.7 & 0.6 & 0.1 \\
Increased ventilation & 8.0 & 2.4 & 0.9 & 0.3 & 0.0 \\
Window shading & 4.1 & 1.0 & 0.2 & 0.0 & 0.0 \\
Window shading + & & & & & \\
increased ventilation & 3.3 & 0.7 & 0.1 & 0.0 & 0.0 \\
\hline$R C P 2.6-2050 s:$ & & & & & \\
No intervention & 17.0 & 10.0 & 5.6 & 2.8 & 0.9 \\
Increased ventilation & 12.5 & 4.2 & 2.0 & 0.8 & 0.2 \\
Window shading & 7.7 & 3.5 & 1.3 & 0.1 & 0.0 \\
Window shading + & & & & & \\
increased ventilation & 6.1 & 2.0 & 0.5 & 0.1 & 0.0 \\
\hline$R C P 4.5-2050 s:$ & & & & & \\
No intervention & 26.9 & 17.8 & 9.4 & 4.3 & 1.6 \\
Increased ventilation & 20.1 & 7.3 & 3.1 & 1.2 & 0.4 \\
Window shading & 13.7 & 6.2 & 2.2 & 0.3 & 0.0 \\
Window shading + & & & & & \\
increased ventilation & 10.6 & 3.1 & 0.9 & 0.1 & 0.0 \\
\hline$R C P 8.5-2050 s:$ & & & & & \\
No intervention & 31.7 & 22.4 & 13.5 & 7.7 & 3.6 \\
Increased ventilation & 24.7 & 11.4 & 5.8 & 2.4 & 0.7 \\
Window shading & 19.5 & 11.3 & 6.2 & 2.3 & 0.3 \\
Window shading + & & & & & \\
increased ventilation & 16.2 & 6.2 & 2.7 & 0.5 & 0.0 \\
\hline & & & & & \\
\hline
\end{tabular}

Table 6 summarizes the impacts of the overheating control strategies on different comfort factors including maximum hourly indoor air and operative temperatures as well as PPD in summer, for the living areas of the building. Overall, the comfort factors deteriorate under the future climate conditions compared to the recent or historical climate. Notwithstanding, the indoor comfort factors are improved with the implementation of the strategies. The maximum indoor air temperature is about $31^{\circ} \mathrm{C}$ under the recent climate, and is reduced $2.5^{\circ} \mathrm{C}$ with the cumulative implementation of the strategies. In contrast, the maximum indoor air temperature is about $33^{\circ} \mathrm{C}$ under the RCP8.5-2050s climate, and is reduced $2.7^{\circ} \mathrm{C}$ with the cumulative implementation of the strategies. The decrease in operative temperatures of the building with implementation of the strategies follows the same trend as the indoor air temperatures. Similar to the impact on the discomfort hours, window shading gave the biggest reduction of the PPD values, improving the comfort conditions.

Table 6. Maximum hourly indoor air and operative temperatures and PPD values in summer for the building under the different climates.

\begin{tabular}{|c|c|c|c|}
\hline Description & $\begin{array}{l}\text { Indoor air } \\
\text { temperature }\end{array}$ & $\begin{array}{l}\text { Operative } \\
\text { temperature }\end{array}$ & $\begin{array}{l}\text { PPD- } \\
\text { index }\end{array}$ \\
\hline \multicolumn{4}{|l|}{ 1961-1990: } \\
\hline No intervention & 30.9 & 31.1 & 56.6 \\
\hline Increased ventilation & 30.5 & 30.7 & 50.2 \\
\hline Window shading & 28.2 & 28.3 & 15.2 \\
\hline $\begin{array}{l}\text { Window shading + } \\
\text { increased ventilation }\end{array}$ & 28.1 & 28.2 & 15.0 \\
\hline \multicolumn{4}{|l|}{ 1981-2010: } \\
\hline No intervention & 31.1 & 31.4 & 63.9 \\
\hline Increased ventilation & 30.1 & 30.5 & 48.3 \\
\hline Window shading & 28.6 & 28.8 & 22.6 \\
\hline $\begin{array}{l}\text { Window shading }+ \\
\text { increased ventilation }\end{array}$ & 28.5 & 28.7 & 21.9 \\
\hline \multicolumn{4}{|l|}{ RCP2.6-2050s: } \\
\hline No intervention & 32.6 & 32.8 & 85.0 \\
\hline Increased ventilation & 31.6 & 31.8 & 70.6 \\
\hline Window shading & 29.8 & 29.9 & 38.1 \\
\hline $\begin{array}{l}\text { Window shading }+ \\
\text { increased ventilation }\end{array}$ & 29.4 & 29.5 & 32.4 \\
\hline \multicolumn{4}{|l|}{ RCP4.5-2050s: } \\
\hline No intervention & 32.9 & 33.2 & 88.1 \\
\hline Increased ventilation & 31.8 & 32.0 & 72.5 \\
\hline Window shading & 30.0 & 30.1 & 46.0 \\
\hline $\begin{array}{l}\text { Window shading }+ \\
\text { increased ventilation }\end{array}$ & 29.7 & 29.9 & 45.5 \\
\hline \multicolumn{4}{|l|}{ RCP8.5-2050s: } \\
\hline No intervention & 33.0 & 33.1 & 90.4 \\
\hline Increased ventilation & 32.1 & 32.1 & 79.2 \\
\hline Window shading & 30.9 & 30.9 & 59.2 \\
\hline $\begin{array}{l}\text { Window shading }+ \\
\text { increased ventilation }\end{array}$ & 30.3 & 30.3 & 49.5 \\
\hline
\end{tabular}

The effectiveness of the strategies in reducing the cooling energy demand of the building under the different climates is summarized in Fig. 14. The cooling is via air conditioning, activated only if the other strategies cannot entirely achieve the maximum indoor temperature set-point of $26^{\circ} \mathrm{C}$. The cooling loads are reduced between $62-76 \%$ with the cumulative implementation of the strategies. The reduction of cooling energy demand for window shading is at least a factor-of-three more than that of increased ventilation. The additional cooling energy benefit achieved when window shading and increased ventilation are combined is marginal compared to when only window shading is implemented. This energy benefit ranges between 0.1 to $0.6 \mathrm{kWh} / \mathrm{m}^{2}$. 


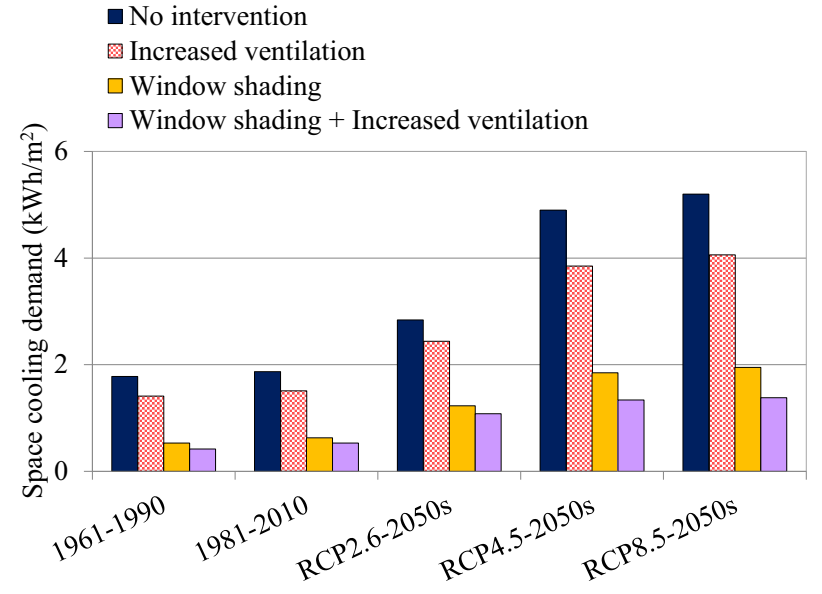

Fig. 14. Space cooling demand of the building with and without overheating control strategies under different climate scenarios.

\section{DISCUSSION AND CONCLUSIONS}

This paper has examined the implications of projected changes in future climate for energy and indoor thermal comfort performance of a multi-storey residential building in Sweden. The analysis is based on low, medium and high RCP climate change scenarios for the year 2050-2059 time frame. The findings of this study suggest that future climate change will significantly influence energy and indoor climate performance of Swedish residential buildings, and that thermal performance of buildings could be improved with effective overheating control and adaptation strategies.

The analysis show that heating demand would decrease significantly while cooling demand would increase considerably, as noted in previous studies [15, 19, 23-26]. For the building analysed in this study, space heating demand decreased between $15-27 \%$ while space cooling demand increased between $60-192 \%$ under the projected future climates, compared to the recent climates of Sweden.

Overall, the percentage of total occupant hours with overheating and thermal discomfort increase under the climate change conditions. For the analysed building, indoor temperature and operative temperatures increased for the future climates, compared to the recent climate. Furthermore, the PPD for the building are significantly higher under the future climates compared to the recent climate. However, implementation of control measures as external window shading and increased ventilation significantly reduced overheating and discomfort in the analysed building. This consequently reduced the cooling demand of the building, both under the recent and future climate scenarios.

Profile and magnitude of internal heat gains can significantly impact on indoor air temperatures, overheating risk and cooling loads of buildings [39]. In this analysis, standard electrical appliance and lighting are modelled for the building studied. The implications of improved electrical appliance and lighting which also reduce internal heat gain were not considered. Internal heat gain could be more than halved when household electrical equipment are based on best available instead of standard technologies [33]. However, reduced internal heat gains also result in increased balance of energy that need to be supplied from heating systems. Hence changes in both heating and cooling demands need to be considered in determining the overall implications of reduced internal heat gain from improved electrical equipment.

In summary, this study shows that climate change will significantly affect buildings' energy performance and indoor thermal comfort conditions. This increases the importance of strategies to improve overall energy performance of buildings while minimising overheating risk. Effective adaptation strategies as analysed in this study could significantly improve thermal performance of Swedish buildings under both current and anticipated future climate conditions.

\section{REFERENCES}

1. IPCC, Climate Change 2014: Mitigation of Climate Change. Contribution of Working Group III to the Fifth Assessment Report of the Intergovernmental Panel on Climate Change. 2014.

2. IPCC, Summary for Policymakers. In: Global Warming of $1.5^{\circ} \mathrm{C}$. An IPCC Special Report on the impacts of global warming of $1.5^{\circ} \mathrm{C}$ above preindustrial levels and related global greenhouse gas emission pathways, in the context of strengthening the global response to the threat of climate change, sustainable development, and efforts to eradicate poverty [Masson-Delmotte, et al. (eds.)]. World Meteorological Organization, Geneva, Switzerland, 32 pp. 2018.

3. NOAA, 2019 was 2 nd hottest year on record for Earth say NOAA, NASA. Accessed at https://www.noaa.gov/news/2019-was-2nd-hottestyear-on-record-for-earth-say-noaa-nasa 22/01/2020. 2020.

4. World Meteorological Organisation, 2019 set to be 2nd or 3rd warmest year on record. Accessed at https://public.wmo.int/en/media/news/2019-set-be2nd-or-3rd-warmest-year-record 22/01/2020. 2020.

5. Swedish Meteorological and Hydrological Institute, Klimatscenarier (In English: Climate Scenarios). Accessed http://www.smhi.se/klimatdata/framtidens-klimat 2013.

6. IEA, Key world energy statistics. 2018: International Energy Agency.

7. BP, BP Energy Outlook. . Available at https://www.bp.com, 2018.

8. IPCC, Intergovernmental panel on climate change. 2007, IPCC Secretariat Geneva.

9. International Energy Agency, Redrawing the Energyclimate Map: World Energy Outlook Special Report. 2013: OECD/IEA.

10. European Commission, Limiting Global Climate Change to 2 degrees Celsius. The way ahead for 2020 and beyond. 2007, COM/2007/2. 
11. European Commission, Paris Agreement. Accesed at https://ec.europa.eu/clima/policies/international/neg otiations/paris en on 09/01/2017. 2016, EC.

12. Directive 2010/31/EU, Directive 2010/31/EU of the European Parliament and of the Council of 19 May2010 on the energy performance of buildings (Recast), Official Journal of the European Union. L 153, 18/06/2010.

13. Amato, A.D., et al., Regional energy demand responses to climate change: Methodology and application to the Commonwealth of Massachusetts. Climatic Change, 2005. 71(1-2): p. 175-201.

14. Nik, V.M., et al., Future moisture loads for building facades in Sweden: Climate change and wind-driven rain. Building and Environment, 2015. 93, Part 2: p. 362-375.

15. Dodoo, A., L. Gustavsson, and F. Bonakdar, Effects of Future Climate Change Scenarios on Overheating Risk and Primary Energy Use for Swedish Residential Buildings. Energy Procedia, 2014. 61: p. 1179-1182.

16. Rodrigues, L.T., M. Gillott, and D. Tetlow, Summer overheating potential in a low-energy steel frame house in future climate scenarios. Sustainable Cities and Society, 2013(7): p. 1-15.

17. Frank, T., Climate change impacts on building heating and cooling energy demand in Switzerland. Energy and Buildings, 2005. 37(11): p. 1175-1185.

18. Jenkins, D.P., A.D. Peacock, and P.F.G. Banfill, Will future low-carbon schools in the UK have an overheating problem? Building and Environment, 2009. 44(3): p. 490-501.

19. Nik, V.M. and A. Sasic Kalagasidis, Impact study of the climate change on the energy performance of the building stock in Stockholm considering four climate uncertainties. Building and Environment, 2013. 60: p. 291-304.

20. Wang, X., D. Chen, and Z. Ren, Assessment of climate change impact on residential building heating and cooling energy requirement in Australia. Building and Environment, 2010. 45(7): p. 16631682.

21. Berger, T., et al., Impacts of climate change upon cooling and heating energy demand of office buildings in Vienna, Austria. Energy and Buildings, 2014. 80: p. 517-530.

22. Olonscheck, M., A. Holsten, and J.P. Kropp, Heating and cooling energy demand and related emissions of the German residential building stock under climate change. Energy Policy, 2011. 39(9): p. 4795-4806.

23. Nik, V.M., E. Mata, and A.S. Kalagasidis, Assessing the Efficiency and Robustness of the Retrofitted Building Envelope Against Climate change. Energy Procedia, 2015. 78: p. 955-960.

24. Nik, V.M., A. Sasic Kalagasidis, and E. Kjellström, Statistical methods for assessing and analysing the building performance in respect to the future climate. Building and Environment, 2012. 53: p. 107-118.

25. Tettey, U.Y.A., A. Dodoo, and L. Gustavsson, Design strategies and measures to minimise operation energy use for passive houses under different climate scenarios. Energy Efficiency, 2019. 12(1): p. 299-313.

26. Dodoo, A. and L. Gustavsson, Energy use and overheating risk of Swedish multi-storey residential buildings under different climate scenarios. Energy, 2016. 97: p. 534-548.

27. Thorsson, S., et al., Potential changes in outdoor thermal comfort conditions in Gothenburg, Sweden due to climate change: the influence of urban geometry. International Journal of Climatology, 2011. 31(2): p. 324-335.

28. Swedish Meteorological and Hydrological Institute, Dataserier med normalvärden för perioden 19611990. (In English: Data series of normal values for the period 1961-1990). 2009. Accessed at http://www.smhi.se/klimatdata/meteorologi/dataserie r-med-normalvarden-1.7354

29. Swedish Meteorological and Hydrological Institute, Rossby Centre regional atmospheric model RCA4. 2011. Accessed at http://www.smhi.se/en/research/researchdepartments/climate-research-rossby-centre2552/rossby-centre-regional-atmospheric-model-rca41.16562

30. Belcher, S., J. Hacker, and D. Powell, Constructing design weather data for future climates. Building Services Engineering Research and Technology, 2005. 26(1): p. 49-61.

31. StruSoft, VIP-Energy software, Sweden. Available from http://www.strusoft.com/products/vip-energy on 10/01/2019. 2019.

32. Dodoo, A., U.Y.A. Tettey, and L. Gustavsson, On input parameters, methods and assumptions for energy balance and retrofit analyses for residential buildings. Energy and Buildings, 2017. 137: p. 76-89.

33. Dodoo, A., U.Y.A. Tettey, and L. Gustavsson, Influence of simulation assumptions and input parameters on energy balance calculations of residential buildings. Energy, 2017. 120: p. 718-730.

34. Boverkets Byggregler, Boverkets Författningssamling, The national Board of Housing Building and planning, Karlskrona. Accessed at http://www. boverket.se on 10/04/2017, (In Swedish). 2015.

35. Camfil, City pollution. AirMail No. 2. 2014. Accessed at

http://www.camfil.se/FileArchive/Brochures/Airmail/ AirMail 20142 EN.pdf on 12/04/2017.

36. ISO, 7730. Ergonomics of the Thermal Environment: Analytical Determination and Interpretation of Thermal Comfort Using Calculation of the PMV and PPD Indices and Local Thermal Comfort Criteria. International Organization for Standardization., 2005.

37. Socialstyrelsen, Temperaturer inomhus. 2005(917201-972-7).

38. CIBSE, G.A., Environmental design. The Chartered Institution of Building Services Engineers, London, 2006.

39. Peacock, A.D., D.P. Jenkins, and D. Kane, Investigating the potential of overheating in $U K$ dwellings as a consequence of extant climate change. Energy Policy, 2010. 38(7): p. 3277-3288. 